
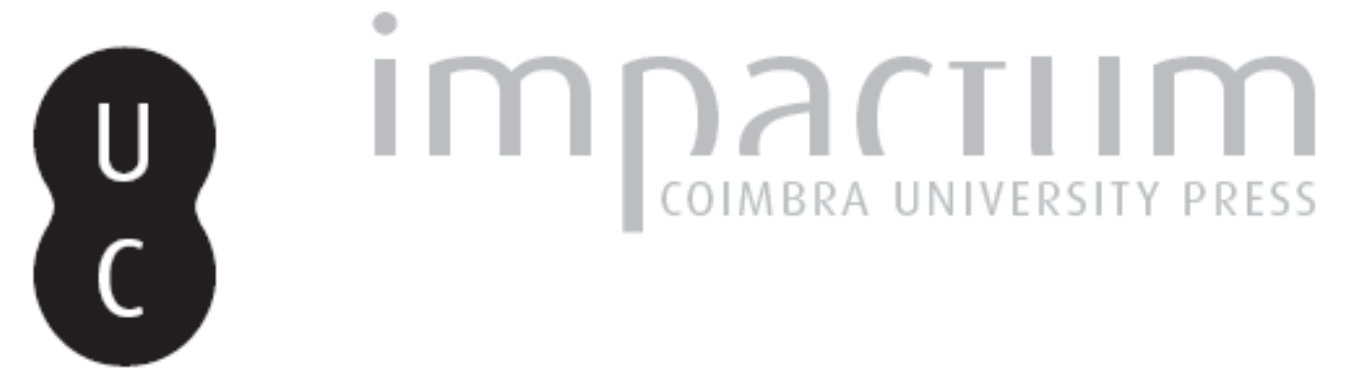

\title{
Combining observed and contingent travel behaviour: the best of both worlds?
}

\author{
Autor(es): $\quad$ Cruz, Luís; Simões, Paula; Barata, Eduardo
}

Publicado por: Imprensa da Universidade de Coimbra

URL persistente:

URl:http://hdl.handle.net/10316.2/35133

DOI:

DOI:http://dx.doi.org/10.14195/2183-203X_40_1

Accessed : $\quad$ 26-Apr-2023 10:18:19

A navegação consulta e descarregamento dos títulos inseridos nas Bibliotecas Digitais UC Digitalis, UC Pombalina e UC Impactum, pressupõem a aceitação plena e sem reservas dos Termos e Condições de Uso destas Bibliotecas Digitais, disponíveis em https://digitalis.uc.pt/pt-pt/termos.

Conforme exposto nos referidos Termos e Condições de Uso, o descarregamento de títulos de acesso restrito requer uma licença válida de autorização devendo o utilizador aceder ao(s) documento(s) a partir de um endereço de IP da instituição detentora da supramencionada licença.

Ao utilizador é apenas permitido o descarregamento para uso pessoal, pelo que o emprego do(s) título(s) descarregado(s) para outro fim, designadamente comercial, carece de autorização do respetivo autor ou editor da obra.

Na medida em que todas as obras da UC Digitalis se encontram protegidas pelo Código do Direito de Autor e Direitos Conexos e demais legislação aplicável, toda a cópia, parcial ou total, deste documento, nos casos em que é legalmente admitida, deverá conter ou fazer-se acompanhar por este aviso.

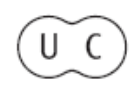




\section{Notaseco NómIcas}

LUÍS-CRUZ / PAULA SIMÕES / EDUARDQ BARATA

COMBINING OBSERVED AND CONTINGENT TRAVEL BEHAVIOUR: THE BEST OF BOTH WORLDS?

MAURO SERAPIQNI / PECDRO LOPES FERREIRA $\wedge$ PATRÍCIA ANTUNES

DOUTORAMENTO HONORIS CAUSA DO BR. ANTÓNIO ARNAUT

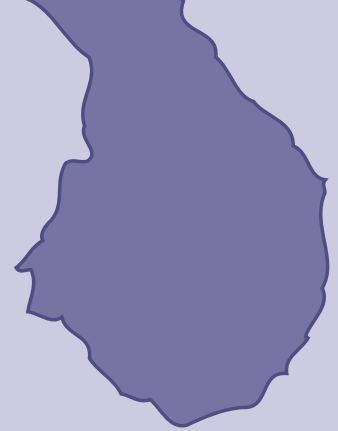

PARTICIPAÇÃO EM SAÚDE: CONCEITOS E CONTEÚDOS 


\section{Combining Observed and Contingent Travel Behaviour: The Best of Both Worlds?}

Luis Cruz / Paula Simões / Eduardo Barata

Os recursos naturais oferecem uma ampla gama de benefícios para a sociedade. Mas muitos destes recursos podem ser irremediavelmente perdidos. Considerando que os esforços de proteção ambiental envolvem custos de oportunidade, a avaliação económica é essencial para permitir aos decisores conhecer os benefícios líquidos das suas decisões, principalmente no caso de benefícios não incorporados nos preços de mercado.

A literatura sobre a avaliação ambiental tem permitido desenvolvimentos significativos. Incidindo sobre os métodos utilizados para avaliar os benefícios relacionados com o uso recreativo de áreas naturais, este trabalho explora o potencial de combinar abordagens com base em preferências reveladas e declaradas. Conclui-se que esta opção impõe esforços adicionais que no entanto serão compensados pela possibilidade de tirar proveito do melhor destes dois mundos.

JEL Classification: Q26; Q51.
Natural resources offer a wide range of benefits to society. But many of these resources can be irrevocably lost if active measures are not adopted. Considering that environmental protection endeavours involve opportunity costs, economic valuation is essential to inform policymakers about the full net benefits of alternative measures, mainly if they are not properly reflected in market prices.

The literature on environmental valuation has been proliferating and significant developments have been achieved. Focusing on the methods used to evaluate the benefits related to the recreational use of natural areas, this paper explores the potential complementarity of approaches based on combined revealed and stated preferences techniques. We conclude that putting together the best of these both worlds imposes additional efforts that are worthwhile.

Les ressources naturelles offrent une vaste gamme d'avantages pour la société. Mais beaucoup de ces ressources peuvent être perdus si des mesures actives ne sont pas adoptées. Considérant que la protection de l'environnement entraîne des coûts d'opportunité, l'évaluation économique est essentielle pour informer les décideurs sur les avantages nets de stratégies alternatives, surtout s'ils ne sont pas correctement reflétés dans les prix du marché.

La littérature sur l'évaluation environnementale a été prolifère et développements significatifs ont été atteints. Mettre l'accent sur les méthodes utilisées pour évaluer les avantages liés à l'utilisation récréative des espaces naturels, cet article explore la complémentarité des approches fondées sur techniques de préférences révélées et énoncées. Nous concluons que rassembler le meilleur de ces deux mondes impose des efforts supplémentaires qui valent la peine. 
Natural areas and environmental resources in general provide a wide diversity of goods and services that are valuable for society. As such, efficient management is strictly necessary and requires benefits to be weighed against costs. However, the public or semi-public condition of these spaces precludes the existence of established markets ensuring an efficient allocation. Public authorities managing these areas are likely to be acquainted with current maintenance costs, but benefits must be estimated indirectly. This estimation is complex because a wide range of benefits is always involved. Present and future outdoor recreation opportunities are among these benefits and are related to multiple activities. They range from the more passive ones such as sitting and relaxing, enjoying the landscape or watching the fauna (e.g., whales or birds), to more active options such as walking, skiing, mountain biking or climbing.

Demand for outdoor recreation in developed countries has been rising and projections point towards this increase continuing. Consequently, growing demand pressure is expected for natural areas. However, knowledge on outdoor recreation remains scant. Very often there is incomplete data about the level of demand. There is also lack of information about visitors' socio-demographic characteristics, their preferences with respect to features of the natural resource and the motivation and characteristics of their visits. Reactions of visitors to changes in current conditions and/or in access prices are also unknown.

In recent decades, researchers have been working hard in order to fill this gap. Researchers aim to produce reliable and structured information on demand, and consequently on the value attached by society. Their ultimate purpose is to support natural areas management. A number of empirical studies have been devoted to the estimation of values associated with the use and non-use of natural resources. Analysis has relied on non-market valuation techniques in a permanent attempt to improve knowledge on demand and welfare.

Non-market valuation techniques are usually structured in two main groups: revealed preferences and stated preferences. In recent years, researches have been recognizing the advantages of combining the use of techniques from both groups. This article summarises the state of this debate and highlights some critical issues, focusing on the methods used to evaluate the benefits related to the recreational use of natural areas.

The analysis is organised as follows. The conceptual and methodological framework underlying non-market valuation is presented in Section 2. Sections 3 and 4 outline the state of the art and the critical issues concerning the most widely used stated preferences (contingent methods and choice modelling) and revealed preferences (travel cost) techniques. Section 5 explores an oriented literature review of the joint application of contingent methods and travel cost methods, in the context of outdoor nature-based recreation. Section 6 concludes.

\section{Economic values and non-market valuation techniques}

The values of environmental services are not usually directly revealed in market transactions mainly because many of them are non-tradable. Accordingly, non-market valuation techniques must be considered to better assess their true economic value and to promote efficiency. A major difficulty in non-market valuation concerns the concept of value itself, which is neither unique nor trouble-free. The study of environmental goods/services involves a wide diversity of aspects adding even more complexity to the concept. So we start this analysis by discussing the concept of total economic value (TEV) of natural resources and suggesting a specific structuring of their multiple dimensions (Section 2.1). The relation between the different dimensions of TEV and non-market valuation techniques is also examined. In Section 2.2, we discuss the possibility and accuracy of using monetary units to evaluate environmental resources. The relation between the components of TEV and the non-market valuation techniques is considered in Section 2.3. 


\subsection{Total Economic Value}

To clarify the concept of TEV we selected the three definitions below, because of their complementary focus. The TEV of a natural resource can be simply defined as the sum of all its marketable and non-marketable values (Torras, 2000). The Earthscan book of The Economics of Ecosystems and Biodiversity (TEEB) complements this definition, presenting the TEV of ecosystems and biodiversity as "the sum of the values of all service flows that natural capital generates now and in the future - appropriately discounted" (Pascual and Muradian, 2010: 188). The definition of ecological values used by Norton and Noonan (2007: 666 ) is also useful to explain the concept of TEV. Their words are: "the whole range of values that humans derive from ecological systems, including services, provision of material resources, aesthetic values attributed to pristine and/or healthy systems, recreation, spiritual and bequest values".

To sum up, the TEV of natural resources includes marketable and non-marketable values, their present and future values and the goods provided can be either material or non-material. As observed by Plottu and Plottu (2007: 55), the concept of TEV follows from a definition and an interpretation of the environment value stemming from a neo-classical field of reflection. The TEV has been disaggregated into two main parts, use and non-use values.

Use value arises from actual, planned or possible use and consists of two branches, actual use value and option value. Actual use value reflects the utility that people derive from direct or indirect use of the resource. Direct use value concerns the active use of the resource, while indirect use value is associated with benefits that people experience indirectly or as a consequence of the primary function of the resource (Torras, 2000: 286). Finally, option value is the value that people place on the potential benefits related to every use that can be realized in the future, even if they are not actual users and/or do not eventually use the resource in the future.

Non-use value refers to the value of safeguarding some good even though there is no present or future planned use by the individual to whom the benefits accrue. This value follows from the own sake of the good or from securing the opportunity for others to derive benefit, either from the use or non-use. The most common categorization separates the non-use component into existence and bequest values. We follow the taxonomy of Pearce et al. (2006: 86) which includes the altruistic value. The altruistic value is the benefit people receive from knowing that the good is available to others in the current generation. The bequest/legacy value is the benefit accruing to people from the assurance that the resource will be preserved and available in the future. The concept of existence value was originally proposed by Krutilla (1967). It is the benefit derived from preserving the good in a context where the individual has no actual or planned use for himself or for anyone else at the present or in the future. This is closely related to the concept of intrinsic value and sometimes not distinguished from (Plottu and Plottu, 2007). However, there is a fundamental difference: existence value depends on individual preferences, while intrinsic values are not anthropocentric; they are independent of human needs and tastes. Figure 1 shows how TEV is structured into separate motivation-based values. 


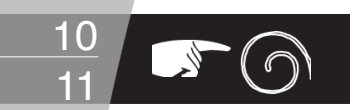

\section{Figure 1: Total Economic Value}

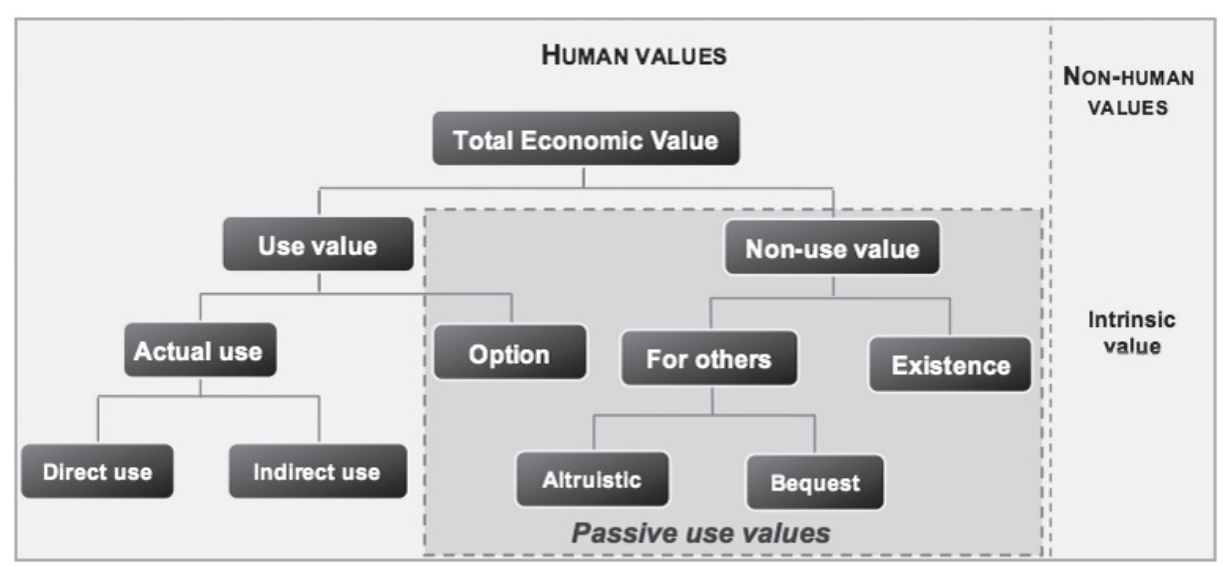

Adapted from Pearce et al. (2006: 87) and Bateman and Langford (1997: 573)

There is less agreement on the notion of passive use value ${ }^{1}$. In line with Adamowicz et al. (1998: 64), we define a passive use value as an economic value derived from a change in environmental attributes that is not reflected in any observable behaviour. Therefore, it includes the option value and all non-use values. Plottu and Plottu (2007: 52) argue that option, use and non-use values are fundamentally different. They claim that actual use values (either direct or indirect) can have a monetary expression since it is only a question of resources allocation. Monetization of passive use values, however, is more complicated because they stem from different levels of choice. Option values belong to a higher level of decision because they will determine the availability of future options. Existence values belong to an even higher level, which will determine future sets of options, so they have an asset dimension. Indeed, those authors explain that difficulties in the monetary evaluation of option and non-use values arise in part because the value ascribed by people reflects a collective concern, a preference as a member of a community and not a personal preference. In a similar line of reasoning, others (e.g. Mill et al., 2007) argue that when answering surveys about the willingness to pay (WTP) for environmental goods, people think as citizens and not as individual consumers. Krutilla (1967: 785), long ago expressed the idea that a sense of public responsibility influences choices concerning the passive use values.

The concept of passive use value coincides with the description of public good. Therefore, without public intervention, resources encompassing these values will not be supplied in the market at the optimum quantity. Nevertheless, in some circumstances, e.g. when resources are considered unique, irreplaceable or endangered, this fraction of TEV may be quite important and accurate decisions can only be taken if TEV is considered.

\subsection{Economic Valuation}

Once the components of TEV are clarified, we have to ask: How can those values be incorporated into the economic analysis? Is it possible to express them in monetary units?

1 There is lack of consensus on how the option value should be categorized. Authors have variously classified option value as a non-use value (Walsh et al., 1984; Kaoru, 1993), as a use value (Pearce et al., 2006: 87) or as an autonomous component (Tietenberg, 2003: 37). 
The appropriate context for economic valuation is conditioned by the scale of environmental changes. Valuation is most meaningful when changes in environmental quantity/quality are small or marginal and keep the asset above some critical level (Turner et al., 2003). Moreover, from a theoretical perspective, the components of TEV are typically presented as additive parts. But, in practice, values with respect to each motivation are not strictly separable and additive. Indeed, attempts have been made to estimate the different components of value, though it has proved to be a very hard task (Cummings and Harrison, 1995).

The discussion above about the components of value follows an anthropocentric and utilitarian stance. Therefore, though it is acknowledged that several purposes can act as determinants of human preferences (e.g., pure self-interest, preservation, environmental stewardship, altruistic, cultural, spiritual and ethical), it is assumed that valuation is anchored on human preferences and focused on instrumental values. However, some voices claim that the worth of an entity for its own sake, independent of human preferences, must also be considered. In this view, some environmental resources should be preserved because they have value in their own right. The ideas of incommensurability (Martinez-Alier et al., 1998) and that monetisation of some non-market environmental values is socially unacceptable (Kumar and Kant, 2007: 517) partially follow from this understanding.

In fact, it is complex to estimate the values related to passive use and intrinsic value can hardly be monetized regardless of the metric chosen. At the same time, it "is indisputable that valuation is a necessary step in the decision making process regarding the use of resources", as noted by Tacconi (1995: 229). Therefore, monetary estimates obtained through rigorous studies must be taken into account in decision-making processes and should be integrated in a pluralistic and holistic valuation.

\subsection{Non-market environmental valuation techniques}

As explained above, non-market valuation techniques are required to estimate the welfare benefits accruing from the use and non-use of natural resources. Use values relate to some use, activity or traceable economic behavioural trail, so they can be estimated using Revealed Preferences (RP) techniques. Indeed, RP methods recover people's preferences from actual behaviour and this information is used to work out monetary welfare measures. Values are inferred from the observation of behaviour in related markets, thus they are also called indirect methods.

Passive use values are independent of any actual use of resources by the person evaluating them, so they have no clear behavioural footprint. Because of that, these values can only be estimated using Stated Preferences (SP) techniques. SP methods use data derived from what people state when directly asked to declare their choice, evaluation or (dis)agreement. Hence, they are also called direct methods. Accordingly, the estimation of both use and passive use values is only possible using SP techniques.

Figure 2 summarizes, diagrammatically, the main RP and SP techniques used in non-market environmental valuation. 


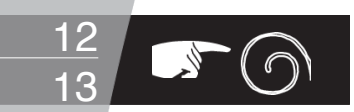

\section{Figure 2: Non-market valuation techniques}

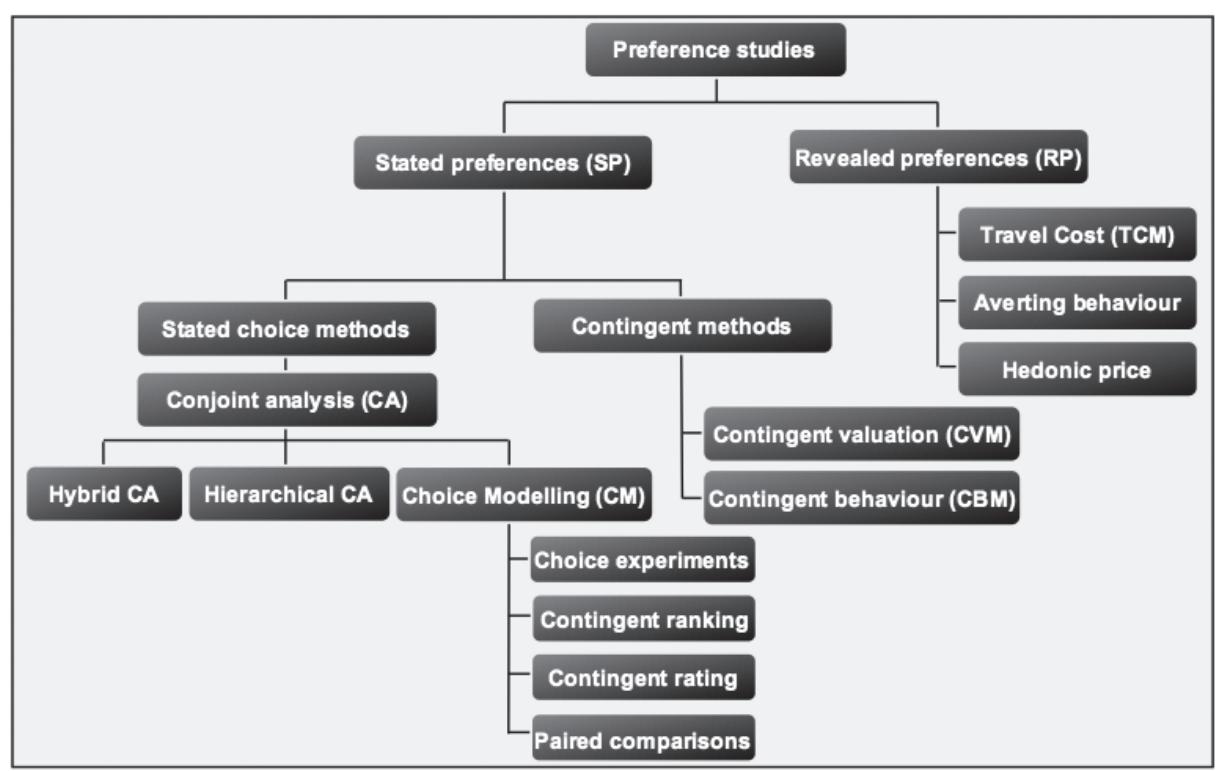

Adapted from Alriksson and Öberg (2008: 246)

The group of the RP methods includes three main techniques conceptually different: the averting behaviour method ${ }^{2}$, the hedonic price method ${ }^{3}$ and the travel cost method (TCM). The group of SP methods has two main ramifications, one made up of the contingent methods and the other of stated choice models derived from the conjoint analysis (CA). Among the RP methods, the TCM is the most widely used, while the contingent valuation method (CVM) is the most well-known among the SP techniques. Application of the choice modelling (CM) has been growing rapidly, such as the combination of TCM with contingent methods. In the following sections we focus on these valuation techniques.

\section{Contingent Methods}

The CVM was originally suggested by Ciriacy-Wantrup in 1947, but its first empirical application was made by Davis in the 1960s to estimate the economic value of big game hunting in Maine backwoods (Mitchell and Carson, 1989: 9). The CVM is a survey-based methodology which

2 The averting behaviour method, also known as defensive behaviour method, is based on the recognition that people are willing to make expenditures which protect themselves from risks, namely from the environmental ones (Whitehead et al., 2008: 874). It is assumed that rational people will take defensive behaviour as long as the value of the damage avoided exceeds the costs of the protective action. The most common application of the averting behaviour method involves health valuation (Dickie, 2003: 396).

3 The hedonic price method estimates the value of a non-market good by observing behaviour in the market for a related private good (Pearce et al., 2006: 93). The non-market good is implicitly traded in that market as it is a characteristic of the transacted good. The most common application of the hedonic theory to environmental valuation has been in housing markets. However, the method has also been used to analyse other markets, such as the labour market (Taylor, 2003: 333). 
involves the construction of a hypothetical market where a proposed environmental program would be transacted. After the description of the hypothetical scenario, people are asked directly or indirectly how much they would be willing to pay/accept (WTP/A) to guarantee/avoid the proposed action ${ }^{4}$. The method is based on the assumption that individuals are able to identify the amount they would be WTP/A and that they will report the true value if the questionnaire is correctly designed. There is general agreement that the CVM is the most versatile and powerful methodology for estimating non-market environmental values (Pearce et al., 2006: 126). Several years of research and empirical application created the necessary space so that many methodological issues could be raised and discussed. Among these issues there is the analysis of the effects of the different types of bias, the choice of the elicitation format (iterative bidding, open ended (OE), dichotomous choice (DC), payment cards) and the treatment of uncertainty.

The contingent behaviour method (CBM) refers to the use of hypothetical questions to get knowledge about behaviour in constructed scenarios. The CBM has been used mainly in the evaluation of resources used for recreational purposes. Respondents have been asked about their intended visitation behaviour given a proposed change in price, quality or access conditions (Grijalva et al., 2002; Cameron, 1992; Lienhoop and Ansmann, 2011).Two main formats have been used: the reassessed contingent behaviour (RCB) and the intended contingent behaviour (ICB). These two formats differ in the relation to the reference period for the contingent behaviour question (Simões et al., 2013a). However, the autonomous application of this method is quite rare (Betz et al., 2003 is one of the few examples). The CBM has been applied jointly with a RP method, mostly TCM, to take advantage of the strengths of both techniques. Ribaudo and Epp (1984) is one of the earliest applications.

$\mathrm{CM}$ is a family of survey-based methodologies which has its roots in conjoint analysis ${ }^{5}$ (Adamowicz et al., 1999: 461). It models preferences for goods described as sets of attributes, which can be quantitative or qualitative in nature and have different levels. Each combination of attributes is an alternative in the consumer's choice set. The inclusion of price as one of the attributes and the status quo situation as one of the alternatives enables the indirect estimation of the WTP/A and the relative values of different attributes. The CM method is consistent with Lancaster's characteristics theory of value which assumes that the utility consumers receive from the consumption of a good can be decomposed into the utilities from the component characteristics (Hanley et al., 2001: 436). In a CM valuation exercise respondents are presented with various alternative descriptions of a good, distinguished by variations in the levels of the underlying attributes, and must choose one of the alternatives, rank or rate them. These different ways of measuring preferences correspond to the different variants of the $\mathrm{CM}$ method displayed in Figure 2. These four main variants differ in the degree of complexity, in the information provided and in the ability to produce WTP/A estimates consistent with welfare measures.

$\mathrm{CM}$ techniques provide a natural way of analysing environment multidimensionality, but were not developed in the context of environmental economics. The earlier applications were made in the fields of psychometrics, marketing and transport (Mackenzie, 1990). The earliest application of CM in the environmental field we could find was conducted by Sinden (1974), who applied the TCM and paired comparisons in the valuation of recreational and aesthetic experiences. About a decade later, Rae (1981) used contingent ranking to evaluate air quality improvements in Mesa Verde National Park. The application of CM in the environmental field has been expanding rapidly since the beginning of the 1990s. In the earlier empirical analysis using CM on environmental valuation, it was mainly applied in parallel with the CVM or the TCM to compare the results of the different methods. Hence, assessing convergent validity was one of the researchers' aims.

Finally, SP methods have been approached differently in literature. Following the recognition of its usefulness and general validity, much research on the CVM has been devoted to the analysis of 
its main biases and ways of overcoming them. The discussion regarding the application of $\mathrm{CM}$ in environmental non-market valuation has been more focused on its advantages relative to the CVM and on the comparison of results across techniques.

Additionally, one can say that the categorization of SP methods proposed in Figure 2 is not unusual, but for some reason authors have not came to an agreement yet. Concerning contingent methods, we consider that CVM and CBM are two different non-market valuation methods. The difference is that CVM elicits a value statement while CBM deals with changes in behaviour. Ellingson and Seidl (2007) and Alberini et al. (2007) are among the authors sharing a similar view. A different perspective was expressed, e.g., by Loomis and McTernan (2014) who classify the CVM as a type of contingent behaviour method and consider contingent behaviour as a class of methods that can be also called stated preference methods. We argue that the distinction should be favoured on the benefits of rigor and accuracy of terminology. In the same way, despite the fact that the choice experiment format of $\mathrm{CM}$ method may be seen as a generalization of the CVM (Adamowicz et al., 1998), researchers have always kept on the distinction.

\section{The Travel Cost Method}

The TCM has been the RP technique favoured to assess the actual use value of natural and semi-natural areas visited for recreation purposes (Adamowicz et al. 1994). It has been applied to different natural resources and recreational activities with several specific objectives lying behind its application. An obvious one is to assess the value of current benefits in order to know the extent of the loss if the resource were to be employed for other purposes. A second reason for using the TCM is to predict the benefits accruing from the creation of a new site similar to other(s) already used for recreation purposes. A third classical motivation is the need to understand how different characteristics add to the resource's economic value. Related to the latter goal is the need to assess how a change in sites' characteristics (e.g., a quality change) affects users' well-being. The origins of the TCM are attributed to Hotelling (1947). The earlier published empirical studies that apply the method include the works by Trice and Wood (1958) and Clawson (1959). Earlier applications refer mainly to the estimation of the monetary value of actual users' benefits derived from water based recreational activities (see, e.g., McConnell and Strand, 1981; Vaughan and Russell, 1982; Desvousges et al., 1983; Trice and Wood, 1958). The TCM is now applied to an extensive spectrum of recreational sites, such as forests, parks, lakes, rivers, beaches, heritage sites and related activities (e.g., fishing, kayaking, rock and ice climbing). These sites and activities have two main common features: users must travel to the site to enjoy it and access is free or only a nominal entrance/licence fee is charged.

The implicit price (or travel cost) is given by travel expenditures. The method is based on the premises that visit frequency to a recreational site declines with increasing travel distances (due to increasing costs) and that individuals answer to changes in travel costs in a similar manner to changes in site entrance fees ${ }^{6}$. The idea is that the observation of the travel cost that individuals bear to gain access to recreational sites makes it possible to infer how individuals value each site. Travel costs may include several components, such as travel expenditures, entrance fees, the opportunity cost of time, on-site expenditures and expenditure on equipment. A number of factors, such as substitution possibilities and socio-demographic characteristics act as demand determinants and in explaining visitors' recreation behaviour. These factors are believed to describe the demand for trips as visitors with particular characteristics travel to specific sites with preferred attributes to attain the desired recreation experience (Shrestha et al., 2007).

Given the multiplicity of variants or versions of the TCM that have been conceived along the years, it is enlightening to provide an overview of the developments usually grouped under the umbrella of the TCM. Table 1 summarizes the discussion regarding the main versions of the TCM that have been occupying the research agenda.

6 For an interesting theoretical treatment of this aspect, see Bowes and Loomis (1980: Section II). 


\section{Table 1: Versions of the Travel Cost Method}

\begin{tabular}{|c|c|c|c|c|c|}
\hline & \multirow{2}{*}{\multicolumn{2}{|c|}{ Version }} & \multirow{2}{*}{ Seminal work } & \multicolumn{2}{|c|}{ Choice } \\
\hline & & & & Number of sites & Time \\
\hline \multirow{3}{*}{ 氮 } & \multicolumn{2}{|l|}{ Zonal } & Hotelling (1947)* & $\begin{array}{l}\text { One site, several } \\
\text { origins }\end{array}$ & \multirow{8}{*}{$\begin{array}{l}\text { Number of trips } \\
\text { during a period of } \\
\text { time. }\end{array}$} \\
\hline & \multicolumn{2}{|l|}{ Individual } & Brown and Nawas (1973)* & $\begin{array}{l}\text { One site, several } \\
\text { individuals }\end{array}$ & \\
\hline & \multicolumn{2}{|l|}{ Hybrid } & $\begin{array}{l}\text { Brown et al. (1980) and } \\
\text { Peterson et al. (1982) }\end{array}$ & $\begin{array}{l}\text { One site, several } \\
\text { individuals and } \\
\text { origins }\end{array}$ & \\
\hline \multirow{9}{*}{ 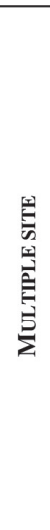 } & \multirow{2}{*}{$\begin{array}{l}\text { Regional } \\
\text { Recreation } \\
\text { Demand }\end{array}$} & $\begin{array}{l}\text { Demand } \\
\text { system a) }\end{array}$ & $\begin{array}{l}\text { Burt and Brewer (1971) } \\
\text { Brown and Hansen (1974) }\end{array}$ & \multirow{5}{*}{$\begin{array}{l}\text { Several sites, several } \\
\text { origins/ individuals }\end{array}$} & \\
\hline & & Gravity & Cesario and Knetsch (1976) & & \\
\hline & \multicolumn{2}{|c|}{ Varying parameter $^{\mathrm{b})}$} & Vaughan and Russell (1982) & & \\
\hline & \multicolumn{2}{|l|}{ Pooled } & Smith and Desvousges (1985) & & \\
\hline & \multicolumn{2}{|c|}{ Hedonic Travel Cost } & Brown and Mendelsohn (1984) & & \\
\hline & \multirow{3}{*}{$\begin{array}{l}\text { Random } \\
\text { Utility }\end{array}$} & $\begin{array}{l}\text { Site } \\
\text { choice }\end{array}$ & $\begin{array}{l}\text { Hanemann (1978 apud Kling } \\
\text { and Crooker, 1999) }\end{array}$ & \multirow{4}{*}{$\begin{array}{l}\text { Several sites, several } \\
\text { individuals }\end{array}$} & $\begin{array}{l}\text { Selection made at } \\
\text { a choice occasion. }\end{array}$ \\
\hline & & Linked & $\begin{array}{l}\text { Bockstael et al. (1987) } \\
\text { Bockstael et al. (1989) }\end{array}$ & & \multirow{3}{*}{$\begin{array}{l}\text { Selection made at } \\
\text { a choice occasion } \\
\qquad+ \\
\text { Number of trips } \\
\text { during a period of } \\
\text { time. }\end{array}$} \\
\hline & & $\begin{array}{l}\text { Repeated } \\
\text { choice }\end{array}$ & $\begin{array}{l}\text { Bockstael et al. (1989) } \\
\text { Morey et al. (1993) }\end{array}$ & & \\
\hline & \multicolumn{2}{|c|}{ Kuhn-Tucker } & Phaneuf et al. (2000) & & \\
\hline
\end{tabular}

* These authors presented the original ideas of the model, but did not perform the first empirical application.

a) Also called "multiple equation", "partitioning" (Mendelsohn, 1985) and "site-specific multiple site model" (Ward and Beal, 2000: 135).

b) Also known as generalized travel cost model (Smith and Desvousges, 1985).

Table 1 suggests a distinction between the two broad groups of methods: the single site and the multiple site versions. The table also shows that two main frameworks can be identified regarding time. One analyses the number of trips through a specific period. Another examines the choice of a site from a set of substitute sites at a moment in time. This summary does not exhaust all the possibilities since many variants of the model have been applied and the TCM remains in continuous refinement. Further, hybrid models, which encompass features of more than one of the models, have been applied in empirical analysis.

Typically, in single site models the quantity demanded is the number of trips to a recreational site or the visitation rate during a certain period. The price is given by the (travel) cost paid to reach the site. Since visitors live at different distances from the recreational site and make a different number of trips, it is possible to observe different quantities corresponding to different price levels. A negative relationship between quantity and price is expected. This approach is useful when the objective is to estimate the total use/access value of the site or the value associated with changes in the access cost (Simões et al., 2013b). It requires less data than multiple site models and is particularly suitable when the number of substitutes sites is small (Parsons, 2003: 324). Single site models are applied in three possible ways: as a zonal travel cost model (ZTCM), as an individual travel cost model (ITCM) or using a hybrid structure.

The label multiple site models is used to identify the models to estimate recreation demand dealing with the choice between substitute sites (which may take into account the number of 
trips made to each of the recreational sites). The main versions are: the regional recreation demand model, which includes the demand system model and the gravity model; the varying parameter model; the pooled model; the hedonic travel cost method and the random utility model (RUM).

In the multiple site framework, the prices and characteristics of substitute sites are important determinants of demand and substitution possibilities between recreational sites are explicitly recognized. Whatever the multiple site model chosen, the selection of the sites to be considered as substitutes and the measurement of the attributes are always complex and crucial tasks.

Overall, the RUM, for multiple site models and the ITCM with count data models, for a single-site model, are dominant in the literature. RUMs have the virtue of directly producing estimates of the Hicksian welfare measures. In spite of its high degree of complexity, the Kuhn-Tucker demand system model seems to be a promising option due to its ability to simultaneously deal with the choice among various sites and the number of visits using a framework that is consistent with choice theory.

\section{Combining observed and contingent travel behaviour}

RP and SP techniques are complementary sources of information. The use of both techniques together allows the researcher to exploit their contrasting strengths and to deal with the weaknesses which are technique specific. Hence, their combination can provide the best source of data having significant advantages compared to the separate application of each one. There are several reasons for this.

On the one hand, RP techniques are more limited in scope as they cannot be used in the estimation of non-use values or passive use values. On the other, SP techniques can be used in the estimation of any kind of value but are more likely to be affected by hypothetical bias. The combination of methods allows overcoming these weaknesses. Moreover, if data gathered by applying two different methods is available, convergent validity can be tested, consistency between SP and RP checked and the underlying structure of preferences compared (Rosenberger and Loomis, 1999; Hanley et al., 2003).

Further, the scope of the analysis can be extended. The combined RP-SP analysis makes possible the evaluation outside the range of what has been historically observed in terms of quantity, quality and/or price. From the policy making standpoint, it may be as important to collect data about the behaviour in the present and/or in the past when particular conditions are/were observed as to address how people would behave if some new conditions were to be observed. This enables the evaluation of actual conditions and the consequences of a proposed policy that, for example, would modify site attributes or the recreational activity cost, but which is not currently or historically observable.

Another important benefit related to the combination of techniques is that it is a mean of more efficient sampling, as often each individual provides more than one observation. The added information improves the efficiency of the estimation, the precision of estimated preferences parameters, hence the accuracy of welfare measures and forecasts (Jeon and Herriges, 2010; Whitehead et al., 2010). Additionally, a suitable experimental design which introduces hypothetical quality and/or price levels is likely to break down the multicollinearity among characteristics.

These benefits have been documented and acknowledged not only by researchers, but also by policy makers. In the H. M. Treasury (2011: 58) Green Book it is stated that:
“(...) In some cases, it will be appropriate to use both techniques together to, for example, check the consistency of results. (...) It is often difficult to assess the reliability of estimates emerging from a single study using a single method. Estimates can be given more credence if different methods, or studies by different researchers, give similar results."

The recognition of the different virtues resulting from the combination of methods has been a gradual process and different objectives have motivated the use of two or more methods in the 
same research. Theoretical developments can be summarized in phases, as follows.

In the earlier phase, the joint application of TCM and an SP technique was designed to evaluate the environmental good in current conditions using different techniques. CVM was the dominant SP method, but was looked with high suspicion because of its hypothetical nature. TCM results were considered more reliable, in spite of method limitations being recognized (Bishop and Heberlein, 1979). One of the main objectives was to address the convergent validity of estimates by evaluating environmental resources using two competing methods (Seller et al., 1985; Cameron, 1992). RP data was assumed to be the most reliable one and was used to validate the SP method.

Next, research moved ahead to a more open vision in which both methods were applied in autonomous estimations without any preconception about which method was the most reliable one (Park et al., 2002; Azevedo et al., 2003; González et al., 2008). In this frame, convergent validity was tested by comparing coefficients' signs, statistical significance and welfare values (see, e.g., Fix and Loomis, 1998). The main objective was to evaluate the environmental good/ service using different competing methods, instead of supplement data from observed behaviour with data from stated behaviour. These are the RP-SP comparison studies (Whitehead et al., 2008).

The third phase has been pioneered by the work of Cameron (1992), who required the cooperation among CVM and TCM. SP data was meant to expand datasets by providing additional observations referring to hypothetical circumstances which go beyond the historical data. Consequently, the focus shifted to the analysis of welfare effects resulting from hypothetical changes in quality/price. The assessments of convergent validity between RP and SP data and of the consistency between revealed and stated preferences were also aspects of main importance. Recently Lienhoop and Ansmann (2011) have introduced a new element in the research agenda, as they conducted a comparison study between TCM-CBM and CVM data.

Concerning econometric treatment, three main routes have been followed. One alternative is to use observations from the two methods in autonomous estimations and to compare the results. In Jeon and Herriges (2010) point of view this is the ideal way to test the consistency of the preferences revealed in the two data sets. Accordingly, this econometric treatment was dominant in the first and second phases. A second option is to stack all the observations in a pooled model. The use of pseudo-panel data models with random effects (RE) or fixed effects (FE) is the third option. The application of two of these alternatives is frequent as well.

Finally, it is important not to ignore that to fully accomplish the benefits of the combined approach additional efforts are needed. First, the survey instrument design is more complex, with the introduction of a set of additional questions (and following a specific sequence). Second, the higher complexity of the survey makes its administration more difficult as it is cognitively more demanding for respondents. Also, longer questionnaires typically induce lower response rates. Finally, additional tests must be computed and therefore data analysis is more complex.

In the evaluation of natural resources that people seek for recreational purposes, the TCM has been predominantly combined with CVM or with CBM. For this reason, Table 2 presents a summary of relevant literature focused on these methods. 

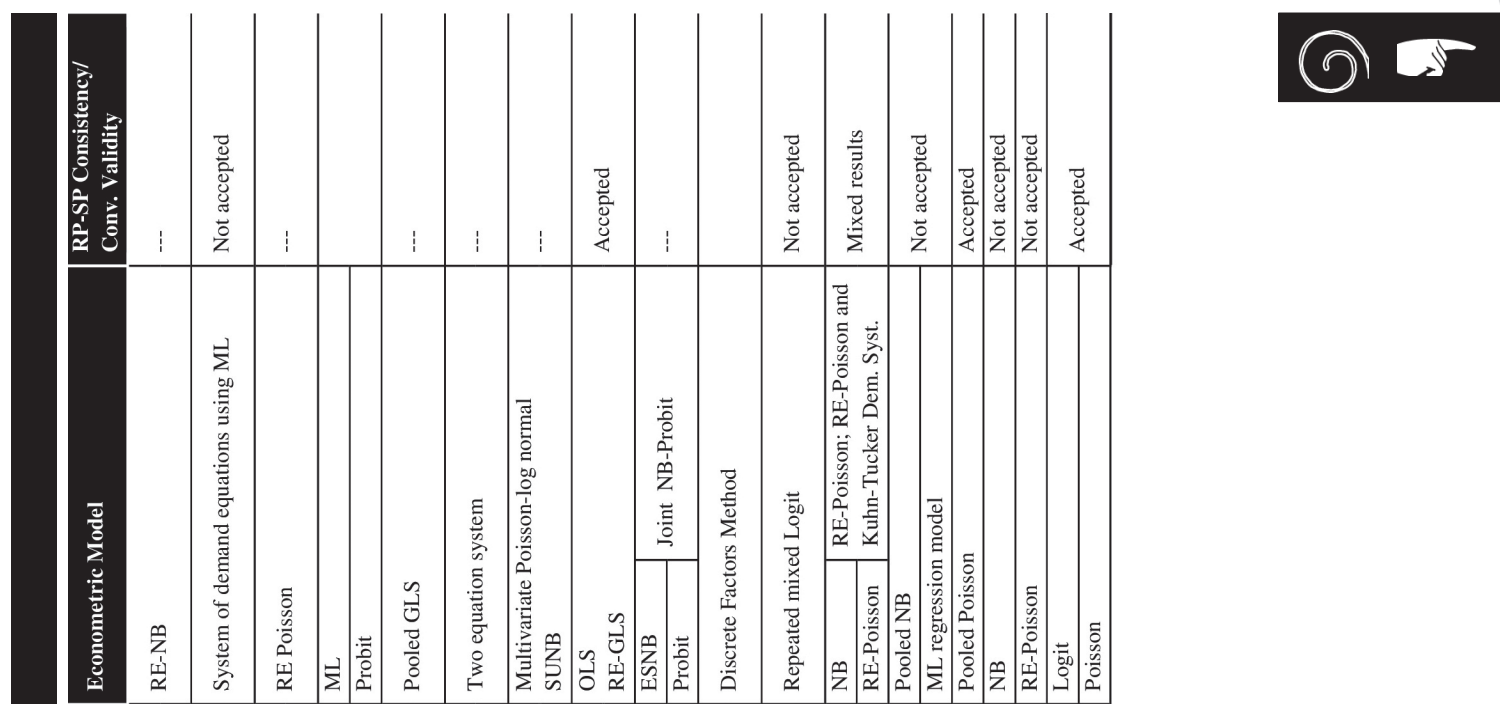

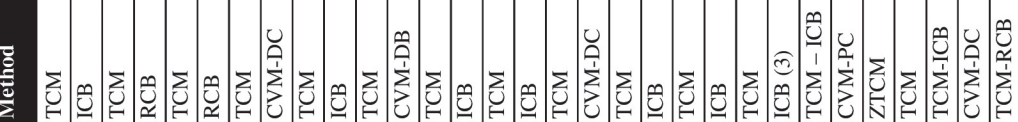

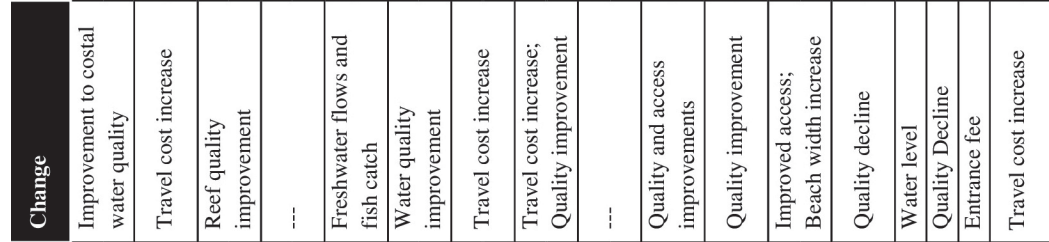

\begin{tabular}{|c|c|c|c|c|c|c|c|c|c|c|c|c|c|c|c|}
\hline 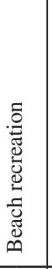 & 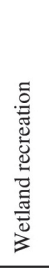 & 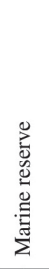 & 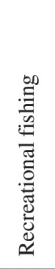 & 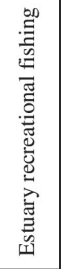 & 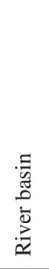 & 兽 & 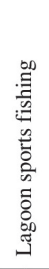 & $\stackrel{\bar{\Xi}}{\widetilde{\Sigma}}$ & 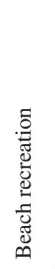 & 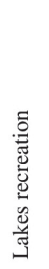 & 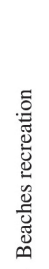 & 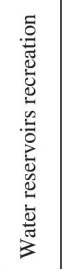 & 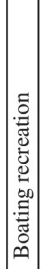 & 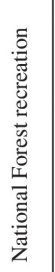 & 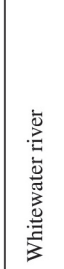 \\
\hline 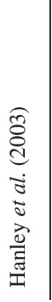 & 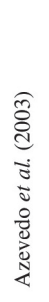 & 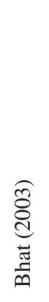 & 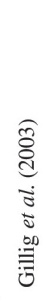 & 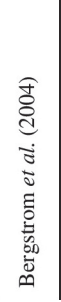 & 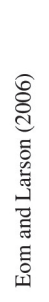 & 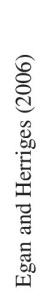 & 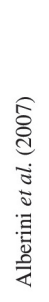 & 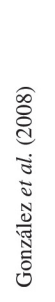 & 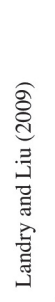 & 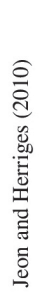 & 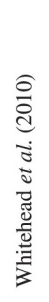 & 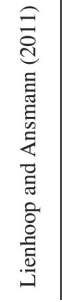 & 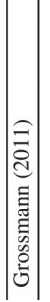 & 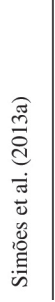 & 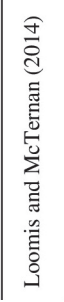 \\
\hline
\end{tabular}




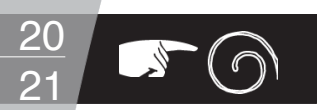

\section{Conclusion}

The first issue in the debate about non-market valuation of environmental goods/natural resources is whether a monetary measure should be used. We agree with those arguing that environmental goods are multidimensional, complex, likely to involve a broad range of aspects (e.g., ecological, scientific, recreational, aesthetic, life support and spiritual) and that environmental goods are sometimes unfamiliar to people asked to evaluate them. Yet we do not think that converting environmental values into monetary units is an affront. Quite the opposite, we consider that when properly done and understood, valuation has the potential to help society to make better-informed choices about the trade-offs that are inherent to the scarcity restrictions of our daily decisions. This does not mean that we consider economic valuation perfect or that it should be used as the sole source of data for policy makers. A similar point of view seems to be shared by the researchers involved in the landmark initiatives TEEB and WAVES, hosted by the United Nations Environment Programme and the World Bank, respectively.

Dating back to the first half of the 20th century, this paper shows how the first theoretical ideas sowed the seeds for the development of the main non-market valuation techniques. Since then, the literature on environmental valuation has been proliferating and significant developments have been achieved. Two main factors appear to be responsible for this dynamism. First, there is a growing awareness that natural resources offer a wide range of benefits to society and that many of these resources can be damaged or irrevocably lost if active measures are not adopted. At the same time, it is recognized that conservation and protection programmes are costly and that public budgets are not sufficient to achieve all the goals. Consequently, economic valuation is perceived as essential to inform policymakers about the benefits of alternative measures as their benefits are not properly reflected in the market prices. Second, there has been a continuous attempt to refine the methodological framework of non-market valuation. This includes a successful enhancement of theoretical models, the improvement of analytical and econometric treatment of the data, the enrichment of datasets and the refinement of the conceptual framework. As methods are enhanced, the reliability of the research results is reinforced.

The path has been traversed by both SP and RP techniques, which sometimes has progressed side by side, but independently; occasionally have competed in reliability and other times, have moved ahead together with the purpose of validation. In recent years, the recognition of their complementarity has been increasing as documented by the cumulative number of empirical studies. So, although convergence tests are always conducted, they are no longer the main objective behind the simultaneous use of techniques from the two groups.

The combination of techniques imposes an additional effort to researchers and respondents. Researchers must construct a longer and more complex questionnaire, deal with low responses rates and use more sophisticated statistical techniques in data analysis. Respondents must recall past behaviour and, at the same time, deal with hypothetical scenarios. However, it has been proved that these extra efforts are worthy for the academia and policymakers. The use of both techniques together allows the researcher to exploit their contrasting strengths and to deal with technique specific weaknesses. Firstly, if data gathered by applying two different methods is available, convergent validity can be tested, consistency between SP and RP checked and the underlying structure of preferences compared. Secondly, more complete information improves the accuracy of welfare measures and forecasts. Finally, the scope of the analysis can be extended to assess - both ex ante and ex post - policy measures and strategies that, e.g., modify site attributes or the recreational activity cost to a status currently or historically unobservable. Indeed, this research article demonstrates how a growing number of authors are finding new avenues of success, opening room for new (and increasingly needed) developments, by putting together the best of both worlds. 
Adamowicz, W.; Louviere, J.; Williams, M. (1994) Combining revealed and stated preference methods for valuing environmental amenities, Journal of Environmental Economics and Management, 26 (3), 271-292.

Adamowicz, W.; Boxall, P.; Williams, M.; Louviere, J. (1998) Stated preference approaches for measuring passive use values: Choice experiments and contingent valuation, American Journal of Agricultural Economics, 80 (1), 64-75.

Adamowicz, W.; Boxall, P.; Louviere, J.; Swait, J.; Williams, M. (1999) Stated-Preference Methods for Valuing Environmental Amenities, in Bateman, I.; Willis, K. (Eds.) Valuing Environmental Preferences, Theory and Practice of the Contingent Valuation Method in the US, EU, and Developing Countries, Oxford, University Press Oxford, 460-482.

Alberini, A.; Zanatta, V.; Rosato, P. (2007) Combining actual and contingent behaviour to estimate the value of sports fishing in the Lagoon of Venice, Ecological Economics, 61 (2-3), 530-541.

Alriksson, S.; Öberg, T. (2008) Conjoint analysis for environmental evaluation: A review of methods and applications, Environmental Science and Pollution Research, 15 (3), 244-257.

Arrow, K.; Solow, R.; Portney, P.; Leamer, E.; Radner, R.; Schuman, W. (1993) Report of the National Oceanic and Atmospheric Administration Panel on contingent valuation, Federal Register, 58 (10), 4602-4614.

Azevedo, C.; Herriges, J.; Kling, C. (2003) Combining revealed and stated preferences: Consistency tests and their interpretations, American Journal of Agricultural Economics, 85 (3), 525-537.

Bateman, I.; Langford, I. (1997) Non-users' willingness to pay for a National Park: An application and critique of the contingent valuation method, Regional Studies, 31 (6), 571-582.

Bergstrom, J.; Dorfman, J.; Loomis, J. (2004) Estuary management and recreational fishing benefits, Coastal Management, 32 (4), 417-432.

Betz, C.; Bergstrom, J.; Bowker, J. (2003) A Contingent trip model for estimating rail-trail demand, Journal of Environmental Planning and Management, 46 (1), 79-96.

Bhat, M. (2003) Application of non-market valuation to the Florida Keys marine reserve management. Journal of Environmental Management, 67 (4), 315-325.

Bishop, R.; Heberlein, T. (1979) Measuring values of extra-market Goods: Are indirect measures biased?, American Journal of Agricultural Economics, 61 (5), 926-930.

Bockstael, N.; Hanemann, W.; Kling, C. (1987) Estimating the value of water quality improvements in a recreational demand framework, Water Resources Research, 23 (5), 951-960.

Bockstael, N.; Hanemann, W.; Strand, I. (1989) Measuring the Benefits of Water Quality Improvements Using Recreation Demand Models, Vol. I, Benefit Analysis Using Indirect or Imputed Market Methods, United Stated Environmental Protection Agency, Washington, D.C.

Bowes, M.; Loomis, J. (1980) A note on the use of travel cost models with unequal zonal populations, Land Economics, 56 (4), 465-470.

Brown, G.; Mendelsohn, R. (1984) The hedonic travel cost method, Review of Economics and Statistics, 66 (3), 427-433.

Brown, R.; Hansen, W. (1974) A Generalized Recreation Day Use Planning Model, Plan formulation and evaluation studies - Recreation, U.S. Army Engineer District, Sacramento, California. 
Brown, W.; Nawas, F. (1973) Impact of aggregation on the estimation of outdoor recreation demand functions, American Journal of Agricultural Economics, 53 (2), 246-249.

Brown, W.; Sorhus, C.; Gibbs, K. (1980) Estimated expenditure by sport anglers and net economic value of salmon and steelhead for specified fisheries in the pacific northwest, Department of Agriculture and Resource Economics, Oregon State University.

Burt, O.; Brewer, D. (1971) Estimation of net social benefits from outdoor recreation, Econometrica, 39 (5), 813-827.

Cameron, T. (1992) Combining contingent valuation and travel cost data for the valuation of nonmarket goods, Land Economics, 68 (3), 302-317.

Carson, R.; Flores, N.; Meade, N. (2001) Contingent valuation: Controversies and evidence, Environmental and Resource Economics, 19 (2), 173-210.

Cesario, F.; Knetsch, J. (1976) A recreation site demand and benefit estimation model, Regional Studies, 10 (1), 97-104.

Chase, L.; Lee, D.; Schulze, W.; Anderson, D. (1998) Ecotourism demand and differential pricing of national park access in Costa Rica, Land Economics, 74 (4), 466-482.

Clawson, M. (1959). Methods of measuring the demand for and value of outdoor recreation, Washington, D.C., Resources for the Future.

Cummings, R.; Harrison, G. (1995) The measurement and decomposition of nonuse values: A critical review, Environmental and Resource Economics, 5 (3), 225-247.

Desvousges, W.; Smith, V.; McGivney, M. (1983) A Comparison of Alternative Approaches for Estimating Recreation and Related Benefits of Water Quality Improvements, U.S Environmental Protection Agency, Washington, D.C.

Dickie, M. (2003) Defensive behavior and damage cost methods, in Champ, P.; Boyle, K.; Brown, T. (Eds.) A Primer on Nonmarket Valuation, Dordrecht, Kluwer Academic Publishers, 395-444.

Egan, K.; Herriges, J. (2006) Multivariate count data regression models with individual panel data from an on-site sample, Journal of Environmental Economics and Management, 52 (2), 567-581.

Ellingson, L.; Seidl, A. (2007). Comparative analysis of non-market valuation techniques for the Eduardo Avaroa Reserve, Bolivia, Ecological Economics, 60 (3), 517-525.

Englin, J.; Cameron, T. (1996) Augmenting travel cost models with contingent behavior data, Poisson regression analysis with individual panel data, Environmental and Resource Economics, 7 (2), 133-147.

Eom, Y.-S.; Larson, D. (2006) Improving environmental valuation estimates through consistent use of revealed and stated preference information, Journal of Environmental Economics and Management, 52 (1), 501-516.

Fix, P.; Loomis, J. (1998) Comparing the economic value of mountain biking estimated using revealed and stated preference, Journal of Environmental Planning and Management, 41 (2), 227-236.

Gillig, D.; Woodward, R.; Ozuna, T.; Griffin, W. (2003) Joint estimation of revealed and stated preference data: An application to recreational red snapper valuation, Agricultural and Resource Economics Review, 32 (2), 209-221.

González, J.; Loomis, J.; González-Caban, A. (2008) A joint estimation method to combine dichotomous choice CVM models with count data models corrected for truncation and endogenous stratification, Journal of Agricultural and Applied Economics, 40 (2), 681-695.

Grijalva, T.; Berrens, R.; Bohara, A.; Shaw, W. (2002) Testing the validity of contingent behavior trip responses, American Journal of Agricultural Economics, 84 (2), 401-414. 
Grossmann, M. (2011) Impacts of boating trip limitations on the recreational value of the Spreewald wetland: a pooled revealed/contingent behaviour application of the travel cost method, Journal of Environmental Planning and Management, 54 (2), 211-226.

H. M. Treasury (2011) The Green Book, Appraisal and Evaluation in Central Government, London, TSO.

Hanley, N. (1989) Valuing non-market goods using contingent valuation, Journal of Economic Surveys, 3 (3), 235-252.

Hanley, N.; Mourato, S.; Wright, R. (2001) Choice modelling approaches: A superior alternative for environmental valuations?, Journal of Economic Surveys, 15 (3), 435-462.

Hanley, N.; Bell, D.; Alvarez-Farizo, B. (2003) Valuing the benefits of coastal water quality improvements using contingent and real behaviour, Environmental and Resource Economics, 24 (3), 273-285.

Hensher, D.; Louviere, J.; Swait, J. (1999) Combining sources of preference data, Journal of Econometrics, 89 (1-2), 197-221.

Hotelling, H. (1947) Letter to the National Park Service. Published in Prewitt (2009) The economics of public recreation, The Prewitt Report, National Park Service, Washington, D.C., Department of the Interior.

Huang, J.-C.; Haab, T.; Whitehead, J. (1997) Willingness to pay for quality improvements: Should revealed and stated preference data be combined?, Journal of Environmental Economics and Management, 34 (3), 240-255.

Jeon, Y.; Herriges, J. (2010) Convergent validity of contingent behavior responses in models of recreation demand, Environmental and Resource Economics, 45 (2), 223-250.

Kaoru, Y. (1993) Differentiating use and nonuse values for coastal pond water quality improvements, Environmental and Resource Economics, 3 (5), 487-494.

Kling, C.; Crooker, J. (1999) Recreation demand models for environmental valuation, in van de Bergh, J. (Ed.) Handbook of Environmental and Resource Economics, Cheltenham, Edward Elgar, 755-764.

Krutilla, J. (1967) Conservation Reconsidered, American Economic Review, 57 (4), 777-786.

Kumar, S.; Kant, S. (2007) Exploded logit modeling of stakeholders' preferences for multiple forest values, Forest Policy and Economics, 9 (5), 516-526.

Landry, C.; Liu, H. (2009) A semi-parametric estimator for revealed and stated preference data An application to recreational beach visitation, Journal of Environmental Economics and Management, 57 (2), 205-218.

Layman, R.; Boyce, J.; Criddle, K. (1996) Economic valuation of the Chinook Salmon sport fishery of the Gulkana River, Alaska, under current and alternate management plans, Land Economics, 72 (1), 113-128

Lienhoop, N.; Ansmann, T. (2011) Valuing water level changes in reservoirs using two stated preference approaches: An exploration of validity, Ecological Economics, 70 (7), 1250-1258.

List, J. (2005) Scientific Numerology, preference anomalies, and environmental policymaking, Environmental and Resource Economics, 32 (1), 35-53.

Loomis, J. (1993) An investigation into the reliability of intended visitation behavior, Environmental and Resource Economics, 3 (1), 183-191.

Loomis, J. (1997) Panel estimators to combine revealed and stated preference dichotomous choice data, Journal of Agricultural and Resource Economics, 22 (2), 233-245.

Loomis, J.; McTernan, J. (2014) Economic value of instream flow for non-commercial whitewater 
boating using recreation demand and contingent valuation methods, Environmental Management, 53 (3), 510-519.

Mackenzie, J. (1990) Conjoint analysis of deer hunting, Northeastern Journal of Agricultural and Resource Economics, 19 (2), 109-117.

Martinez-Alier, J.; Munda, G.; O’Neill, J. (1998) Weak comparability of values as a foundation for ecological economics, Ecological Economics, 26 (3), 277-286.

McConnell, K.; Strand, I. (1981) Measuring the cost of time in recreation demand analysis: An application to sportfishing, American Journal of Agricultural Economics, 63 (1), 153-156.

Mendelsohn, R. (1985) Modelling the Demand for Outdoor Recreation, AERE Workshop on Recreation Demand Modelling, Boulder, Colorado.

Mill, G.; Rensburg, T.; Hynes, S.; Dooley, C. (2007) Preferences for multiple use forest management in Ireland: citizen and consumer perspectives, Ecological Economics, 60 (3), $642-$ $-653$.

Mitchell, R.; Carson, R. (1989) Using Surveys to Value Public Goods: The Contingent Valuation Method, Washignton, D.C., Resources for the Future.

Morey, E.; Rowe, R.; Watson, M. (1993) A Repeated nested-logit model of Atlantic salmon fishing, American Journal of Agricultural Economics, 75 (3), 578-592.

Norton, B.; Noonan, D. (2007) Ecology and valuation: Big changes needed, Ecological Economics, 63 (4), 664-675.

Park, T.; Bowker, J.; Leeworthy, V. (2002) Valuing snorkeling to the Florida Keys with stated and revealed preference models, Journal of Environmental Management, 65 (3), 301-312.

Parsons, G. (2003) The Travel Cost Model, in Champ, P.; Boyle, K.; Brown, T. (Eds.) A Primer on Nonmarket Valuation, Dordrecht, Kluwer Academic Publishers, 269-329.

Pascual, U.; Muradian, R. (2010) The economics of valuing ecosystem services and biodiversity, in P. Kumar (Ed.) The Economics of Ecosystems and Biodiversity - Ecological and Economic Foundations, London, Earthscan, Chapter 5.

Pearce, D.; Atkinson, G.; Mourato, S. (2006) Cost-Benefit Analysis and the Environment: Recent Developments, Paris, OCDE Publishing.

Peterson, G.; Anderson, D.; Lime, D. (1982) Multiple use site demand analysis: an application to the Boundary Water Canoe Area Wilderness, Journal of Leisure Research, 14 (1), 27-36.

Phaneuf, D.; Kling, C.; Herriges, J. (2000) Estimation and welfare calculations in a generalized corner solution model with an application to recreation demand, Review of Economics and Statistics, 82 (1), 83-92.

Plottu, E.; Plottu, B. (2007) The concept of Total Economic Value of environment: A reconsideration within a hierarchical rationality, Ecological Economics, 61 (1), 52-61.

Portney, P. (1994) The contingent valuation debate: Why economists should care, Journal of Economic Perspectives, 8 (4), 3-17.

Rae, D. (1981) Visibility Impairment at Mesa Verde National Park: An Analysis of Benefits and Costs of Controlling Emissions in the Four Corners Area, , in C. R. A. Incorporated (Ed.), Research Project 1742, Palo Alto, California, Electric Power Research Institute.

Ribaudo, M.; Epp, D. (1984) The importance of sample discrimination in using travel cost method to estimate the benefits of improved water quality, Land Economics, 60 (1), 398-403.

Rosenberger, R.; Loomis, J. (1999) The value of ranch open space to tourists: Combining observed and contingent behavior data, Growth and Change, 30 (3), 366-383. 
Seller, C.; Stoll, J.; Chavas, J. (1985) Validation of empirical measures of welfare change: A comparison of nonmarket techniques, Land Economics, 61 (2), 156-175.

Shrestha, R.; Stein, T.; Clark, J. (2007) Valuing nature-based recreation in public natural areas of the Apalachicola River region, Florida, Journal of Environmental Management, 85 (4), 977-985.

Simões, P.; Barata, E.; Cruz, L. (2013a) Joint estimation using revealed and stated preference data: an application using a national forest, Journal of Forest Economics, 19 (3), 249-266.

Simões, P.; Barata, E.; Cruz, L. (2013b) Using count data and ordered models in national forest recreation demand analysis, Environmental Management, 52 (5), 1249-1261.

Sinden, J. (1974) A utility approach to the valuation of recreational and aesthetic experiences. American Journal of Agricultural Economics, 56 (1), 61-72.

Smith, V.; Desvousges, W. (1985) The generalized travel cost model and water quality benefits: A reconsideration, Southern Economic Journal, 52 (2), 371-381.

Tacconi, L. (1995) Rethinking the economic analysis of forests: theory and practice, Forest Ecology and Management, 73 (1-3), 229-238.

Taylor, L. (2003) The Hedonic Method, in Champ, P.; Boyle, K.; Brown, T. (Eds.) A Primer on Nonmarket Valuation, Dordrecht, Kluwer Academic Publishers, 331-393.

Tietenberg, T. (2003) Environmental and Natural Resource Economics, Sixth ed, Boston, Addison-Wesley, Pearson International Edition.

Torras, M. (2000) The total economic value of Amazonian deforestation, 1978-1993, Ecological Economics, 33 (2), 283-297.

Trice, A.; Wood, S. (1958) Measurement of recreational benefits, Land Economics, 34 (3), 195$-207$.

Turner, R.; Paavola, J.; Cooper, P.; Farber, S.; Jessamy, V.; Georgiou, S. (2003) Valuing nature: Lessons learned and future research directions, Ecological Economics, 46 (3), 493-510.

Vaughan, W.; Russell, C. (1982) Valuing a fishing day: An application of a systematic varying parameter model, Land Economics, 58 (4), 450-463.

Ward, F. (1987) Economics of water allocation to instream uses in a fully appropriated river basin: Evidence from a New Mexico wild river, Water Resources Research, 23 (3), 381-392.

Ward, F.; Beal, D. (2000) Valuing Nature With Travel Cost Models, A Manual, Cheltenham, UK and Northampton, Massachusetts, USA, Edward Elgar.

Whitehead, J.; Haab, T.; Huang, J.-C. (2000) Measuring recreation benefits of quality improvements with revealed and stated behavior data, Resource and Energy Economics, 22 (4), 339-354.

Whitehead, J.; Pattanayak, S.; Houtven, G.; Gelso, B. (2008) Combining revealed and stated preference data to estimate the nonmarket value of ecological services: An assessment of the state of the science, Journal of Economic Surveys, 22 (5), 872-908.

Whitehead, J.; Phaneuf, D.; Dumas, C.; Herstine, J.; Hill, J.; Buerger, B. (2010) Convergent validity of revealed and stated recreation behavior with quality change: A comparison of multiple and single site demands, Environmental and Resource Economics, 45 (1), 91-112. 